Volume 2 Issue 2, September 2018: pp. 448-459. Copyright (c) 2018 HOLREV. Faculty of Law, Halu Oleo University, Kendari, Southeast Sulawesi, Indonesia. ISSN: 2548-1762 | e-ISSN: 2548-1754. Open Access at: http://ojs.uho.ac.id/index.php/holrev/

Halu Oleo Law Review is licensed under a Creative Commons Attribution 4.0 International License, which permits unrestricted use, distribution, and reproduction in any medium, provided the original work is properly cited.

\title{
Konsepsi Penyelamatan Dana Desa dari Perbuatan Korupsi
}

\author{
Village Refrigeration Conception of Corruption Requirements
}

\author{
Marten Bunga \\ Dosen Fakultas Hukum Universitas Gorontalo \\ E-mail: marten_bunga@yahoo.co.id \\ Aan Aswari \\ Dosen Fakultas Hukum Universitas Muslim Indonesia \\ E-mail: aanaswari@umi.ac.id \\ Hardianto Djanggih \\ Dosen Fakultas Hukum Universitas Tompotika Luwuk \\ E-mail: hardianto.djanggih@gmail.com
}

\begin{abstract}
This paper aims to analyze the management of village funds from corruption. The problem focuses on how the concept of saving village funds from corruption? This research is in the form of normative legal research with approach of legal norm and legal principles. The result of the research shows that the concept of fund grant from villages from corruption bundles, namely, First, MoU with community with the aim of committing to build village together with village fund monitoring team; Second, establishing an independent team of supervisors to oversee the running of village fund management processes; third, ready to be sworn the village apparatus in the oath by using the scriptures of each religion; four strict sanctions with a view to providing perpetrators of village funds.
\end{abstract}

Keyword: Government; Village Budget; Corruption

Abstrak: Karya ilmiah ini bertujuan untuk menganalisis tentang pengelolaan dana desa dari perbuatan korupsi. Permasalahan berfokus pada bagaimanakah konsep penyelamatan dana desa dari perbuatan korupsi? Penelitian ini berbentuk penelitian hukum normatif dengan pendekatan norma hukum dan asas-asas hukum. Hasil penelitian menunjukkan bahwa Konsep penyelamatan dana desa dari perbuatan korupsi, yaitu, Pertama, MoU dengan masyarakat dengan tujuan berkomitmen membangun desa secara bersama tim pengawasan dana desa; Kedua, pembentukan tim pengawas yang independen untuk mengawasi jalannya proses pengelolaan dana desa; ketiga, siap disumpah yaitu aparat desa di sumpah dengan menggunakan kitab suci masing-masing agama; keempat sanksi yang tegas dengan tujuan untuk memberikan kepada pelaku penyalahgunaan dana desa.

Kata kunci: Pemerintahan; Dana Desa; Korupsi. 


\section{PENDAHULUAN}

Di era sekarang ini keberadaan dari desa sedang mengalami tren atau menjadi primadona bagi siapa saja yang ingin menjadi pejabat publik yang berskala kecil, hal ini di dasarkan pada program dari presiden terpilih sekarang bapak H. Jokowi dan Bapak Wakil Presiden H.M Jusuf Kalla periode 2014-2018 dengan menyentil upaya pengembangan pembangunan dari desa melalui Nawacita III antara lain sebagai berikut "Membangun Indonesia dari pinggiran dengan memperkuat daerah-daerah dan desa dalam kerangka negara kesatuan".1

Melalui visi tersebut sudah sangat membantu upaya pembangunan yang ada di tingkat desa sehingga melahirkan pemerataan pembangunan di segala bidang tanpa ada diskriminasi terkait pembangunan. Adapun upaya pemerintah pusat dalam memaksimalkan Nawacita dari presiden terpilih yang nantinya akan tertuang di dalam RPJM Nasional yang di jabarkan ke RPJM Provinsi dan RPJM Kabupaten/Kota di seluruh Indonesia ini lebih pada penekanan pembangunan dari tingkat bawah sehingga tidak ada lagi apa yang di katakan pembangunan yang hanya menitik beratkan pada kecenderungan pembangunan di Kota, olehnya melalui Nawacita tersebut akan lebih merata pembangunan yang ada.

Adapun plus minus dari pembangunan melalui Nawacita III dari presiden terpilih yang tertuang dalam program dana desa ini di khawatirkan juga akan terjadi penyelewengan dana yang berdampak pada perbuatan korupsi, karena desa belum siap dengan sumber daya manusia yang selama ini keberadaan dari aparatur di pemerintahan desa masih rendah. Sedangkan Pemerintah pusat tahun ini mengalokasikan dana desa senilai Rp 46,9 triliun, dua kali lipat dibanding tahun sebelumnya yang hanya Rp 20 triliun. Dana desa sebesar itu diperuntukkan bagi 74.754 desa yang tersebar di Indonesia. Setiap desa menerima dana desa antara Rp 600 juta sampai Rp 800 juta. Walaupun pemerintah pusat memangkas anggaran untuk semua kementerian dan lembaga negara, namun khusus pos anggaran dana desa tidak ada pengurangan. Ini menunjukkan konsistensi komitmen pemerintah dalam program pengentasan kemiskinan di pedesaan dan pembangunan daerah tertinggal. Mengingat dana desa saat ini peruntukannya difokuskan pada pembangunan infrastruktur desa dan pemberdayaan masyarakat. Terhadap

1 Inggried Dwi Wedhaswary "Nawa Cita", 9 Agenda Prioritas Jokowi-JK", https://nasional.kompas.com/read/2014/05/21/0754454/.Nawa.Cita.9.Agenda.Prioritas.Jokowi-JK. Diakses pada tanggal 1 Maret 2018. 
pengelolaan dana desa, yang dikhawatirkan banyak pihak adalah penggunaannya yang berpotensi dikorupsi. Baik sengaja ataupun tidak disengaja (karena kekurangpahaman cara pemanfaatan maupun pelaporan administratifnya) oleh perangkat desa dan siapa pun yang berkaitan dengan penggunaan dana desa.

Adapun yang menjadi perhatian dari penulis bahwa pengelolaan dana desa akan di khawatirkan berdampak pada ruang yang bisa menjebak para oknum aparat desa dalam penggunaan dana desa dari perbuatan korupsi, hal ini sebagai imbas daripada penanganan masih sangat lemah yang dipengaruhi oleh kinerja penegak hukum ketika diperhadapkan dengan persoalan kejahatan luar biasa ini, ${ }^{2}$ sehingga menarik bagi penulis untuk mengangkat judul “Konsepsi Penyelamatan Dana Desa Dari Perbuatan Korupsi”.

\section{METODE PENELITIAN}

Tipe penelitian ini adalah penelitian hukum normatif, sebagaimana disebutkan Arief Sidharta bahwa penelitian hukum normatif (dogmatik hukum, rechtsdogmatiek), kegiatan ilmiahnya mencakup inventarisasi, memaparkan, interpretasi, dan sistematisasi termasuk evaluasi keseluruhan hukum positif (teks otoritatif) ${ }^{3}$ yang berkaitan dengan konsep penyelamatan dana desa dari perbuatan korupsi. Tipologi penelitian bersifat deskriptif 4 analitis dengan tujuan untuk menggambarkan dan menganalisis konsep ideal tentang penyelamatan dana desa dari perbuatan korupsi yang berakibat pada terhambatnya pembangunan masyarakat desa sebagaimana diamanatkan pada Undang-Undang Nomor 6 Tahun 2014 Tentang Desa. Jenis data yang digunakan adalah data sekunder yang berasal dari bahan hukum primer dan bahan hukum sekunder. Sementara bahan hukum primer adalah perundangan-perundangan yang berkaitan dengan masalah yang menjadi topik kajian. Bahan hukum sekunder adalah meliputi berbagai buku dan karya tulis ilmiah yang terkait dengan bahasa hukum dalam perspektif ilmu hukum serta bahan hukum tersier seperti kamus dan berbagai sumber dari internet. Dengan bahan hukum yang diperoleh, pengolahan, analisis, dan konstruksi data dilakukan dengan cara kuantitatif. Metode yang dipakai menganalisis data adalah metode kualitatif yaitu suatu analisis secara mendalam dan komprehensif.

\footnotetext{
2 Hardianto Djanggih, The Phenomenon Of Cyber Crimes Which Impact Children As Victims In Indonesia. Yuridika, Vol. 33, No. 2, 2018., hlm. 212

3 Sulistyowati Irianto dan Shidarta (ed), Metode Penelitian Hukum; Konstelasi dan Refleksi, Jakarta: Yayasan Pustakan Obor Indonesia, 2011, hlm. 142.

4 Soerjono Soekanto, Pengantar Penelitian Hukum Jakarta: UI Press, 2007, hlm. 51,
} 


\section{ANALISIS DAN PEMBAHASAN}

\section{Konsep Penyelamatan Dana Desa Dari Perbuatan Korupsi}

Penggunaan dana desa sangat menjadi perhatian yang serius baik dari kalangan pemerintah, kalangan pemerhati desa, akademisi dan lain sebagainya, hal ini dilakukan karena di khawatirkan akan banyak para aparatur desa akan terjerat pada persoalan korupsi, sehingga pemerintah sekarang ini banyak melakukan koordinasi baik antar lembaga Negara terkait dengan penanganan desa maupun antar lembaga penegak hukum agar kiranya ada upaya preventif dan represif supaya aparat desa tidak terjerat kasus korupsi.

Korupsi di Indonesia masih menjadi musuh besar. Pemerintah melalui KPK melakukan berbagai inisiasi untuk menumpas tindak pidana korupsi. Berbagai kasus korupsi yang dilakukan oleh beberapa oknum dengan latar belakang pendidikan dan jabatan menjadikan pelajaran yang berharga bagi seluruh lapisan masyarakat dan para pemangku kebijakan. Harus diakui bahwa korupsi adalah kejahatan besar dan merugikan negara dan rakyat. Sementara rakyat masih terkungkung dalam lembah kemiskinan dan keterpurukan, sementara korupsi terus merajalela. Dari semua level tingkatan korupsi seolah-olah sudah menjadi penyakit yang akut dan sulit untuk disembuhkan. Tindak pidana korupsi adalah kejahatan luar biasa yang berdampak sangat bernegara. Aspek sosial, politik, budaya, dan ekonomi mempunyai dampak terhadap tindakan korupsi. Tidak sedikit korupsi yang dilakukan oleh para pejabat publik setingkat menteri, kepala daerah provinsi atau gubernur, kepala daerah Kabupaten/Kota maupun ditingkat level bawah. Padahal jika dikorelasikan dengan tingkat kesejahteraan, keluarga dan pendidikan ratarata berada pada level yang sejahtera. Kesempatan dan peluang serta orientasi kepentingan pribadi atau kelompok yang dapat mempengaruhi perilaku korupsi.

Perilaku korupsi juga menjadi ancaman bagi aparatur Desa dalam penyelenggaraan pemerintah Desa, mulai pengelolaan tanah absentee 5 ikut sebagai contoh hingga kajian ini mengulas potensi terjadinya korupsi di tingkat Desa dalam penggunaan anggaran. Mengingat dalam pelaksanaan Undang-Undang Desa, pemerintah desa digelontor keuangan desa sebanyak 1 sampai 1,5 miliar setiap desa. Hal ini menjadi problem baru bagi pemerintah desa jika tidak dikelola secara baik dan benar. Pengelolaan keuangan desa

5 Elfira Permatasari, Habib Adjie, \& Hardianto Djanggih, Perlindungan Hukum Kepemilikan Tanah Absentee yang Diperoleh Akibat Pewarisan. Varia Justicia, Vol. 14, No. 1, 2018, hlm. 3 
dan manajemen desa harus didampingi secara serius dan berkelanjutan. Pemerintah desa dengan berbagai kekurangan dalam struktur maupun non strukturnya menghantui dalam pelaksanaannya.

Beberapa kasus korupsi yang menimpa pemerintah desa dalam penyalahgunaan wewenang, anggaran, korupsi aset, dan pengadaan barang dan jasa. ${ }^{6}$ Menurutnya KPK menemukan 14 potensi persoalan dana desa yang terdiri dari 4 (empat), yaitu aspek regulasi dan kelembagaan, tata laksana, pengawasan dan sumber daya manusia. Empat aspek itu yang dapat mempengaruhi terjadinya korupsi di pemerintah desa. ${ }^{7}$

Diimplementasikannya Undang-Undang Desa menjadi perbincangan banyak kalangan dalam pengelolaan keuangan desa, yang di dalamnya terdapat pengelolaan sumber daya desa. Pengelolaan dana desa yang diatur dalam Undang-Undang Desa memacu kesiapan kepala desa dalam pelaksanaannya. Berbagai alasan dan faktor disampaikan oleh masyarakat terkait dengan kesiapan kepala desa dan aparatur desa, infrastruktur desa serta kepemimpinan kepala desa.

Undang-Undang Desa memberikan kewenangan secara otonom kepada pemerintah desa dalam mengelola dan mengembangkan desanya. Masyarakat desa lebih sejahtera dengan berbagai program pemberdayaan dan pengelolaan sumber daya desa. Pemerintah desa dapat melakukan pola peningkatan ekonomi desa melalui Badan Usaha Milik Desa (BUMDes), mengatur Anggaran Pendapatan dan Belanja Desa (APBDes) serta melakukan berbagai pembangunan infrastruktur yang dapat menunjang peningkatan ekonomi desa. Dari desa membangun negeri menjadi terwujud. ${ }^{8}$

Sementara itu, dalam sosialisasi pelaksanaan Undang-Undang Nomor 6 Tahun 2014 tentang Desa mengemukakan, bahwa penggunaan dan pemanfaatan wilayah desa sebagai sumber daya desa adalah dalam rangka penetapan kawasan pembangunan sesuai dengan tata ruang kabupaten/kota. ${ }^{9}$ Arah pembangunan kawasan perdesaan sesuai dengan amanat Undang-Undang Desa adalah mencakup pemenuhan kebutuhan dasar,

6 Madril, O. Obral Remisi untuk Koruptor. http://digilib.um.ac.id. Diakses pada tanggal 7 Mei 2018.

7 Maratul Makhmudah, Pencegahan Terhadap Tindak Pidana Korupsi Pemerintahan Desa: Kajian Politik Kebijakan Dan Hukum Pengelolaan Sumber Daya Alam Desa, Fakultas Hukum Universitas Islam Malang, Fakultas Hukum Universitas Brawijaya Malang". Yustisia 95 Mei-Agustus 2016.

$8 \quad$ Ibid. 2016.

9 Yoltuwu, J. M. Pertumbuhan Ekonomi di Daerah Tertinggal (Economic Growth in Disadvantage Area). In Work Meeting Presentation, Ministry of Disadvantage Area Development, Republic of Indonesia, 2013, hlm. 7-9. 
pembangunan sarana dan prasarana desa, pengembangan potensi ekonomi lokal dan pemanfaatan sumber daya alam dan lingkungan secara berkelanjutan. ${ }^{10}$

Oleh karena itu, sesuai dengan Undang- Undang Desa bahwa pembangunan kawasan perdesaan menjadi bagian penting dalam pembangunan desa, termasuk di dalamnya adalah pengelolaan sumber daya alam desa. Pengelolaan sumber daya alam desa harus melibatkan peran serta masyarakat melalui pemberdayaan untuk peningkatan ekonomi masyarakat desa, demi perwujudan teori pengendalian sosial dan teori sistem dalam pemerintahan. ${ }^{11}$ Pelibatan masyarakat dalam pengelolaan sumber daya alam desa adalah dalam rangka menjamin pelaksanaannya berjalan secara maksimal dan optimal. Pembangunan desa oleh masyarakat, dari masyarakat dan untuk masyarakat yang lebih sejahtera dan mandiri. ${ }^{12}$

Pada dasarnya juga sikap masyarakat merupakan kecenderungan individu untuk merespons dengan cara uang khusus terhadap stimulus yang ada dalam lingkungan sosial. Sikap merupakan suatu kecenderungan untuk mendekat atau menghindar, positif atau negatif terhadap berbagai keadaan sosial, apakah itu inisiatif, pribadi, situasi, ide, konsep dan sebagainya.

Menurut Bimo Walgito, sikap itu merupakan organisasi pendapat, keyakinan seseorang mengenai objek atau situasi yang relatif ajeg, yang disertai adanya perasaan tertentu, dan memberikan dasar kepada orang tersebut untuk membuat respons atau perilaku dalam cara tertentu yang dipilihnya. ${ }^{13}$

Berkaitan dengan hal itu, sikap mengandung tiga komponen yang membentuk struktur sikap yaitu:

1. Komponen perseptual yaitu komponen yang berkaitan dengan pengetahuan, pandangan, keyakinan yaitu hal - hal yang berhubungan dengan bagaimana orang memersepsi terhadap objek sikap;

2. Komponen Emosional yaitu komponen yang berhubungan dengan rasa senang atau tidak senang terhadap objek sikap. Rasa senang merupakan hal yang positif, sedangkan rasa tidak senang merupakan hal yang negatif. Komponen ini menunjukkan arah sikap yaitu posistif dan negatif;

10 Maratul Makhmudah, Op.Cit.

11 Aan Aswari, Sibernetika, Teknologi Siber dan Kebutuhan Hukum. Jurnal Lentora, Vol. 3, No. 2, 2016, hlm. 6

12 Ibid.

13 Bimo W, Psikologi Sosial Suatu pengantar, Edisi Revisi Yogyakarta: Andi Opset. 2013. hlm. 95. 
3. Komponen konatif yaitu komponen yang berhubungan dengan kecenderungan bertindak terhadap objek sikap. Komponen ini menunjukkan intensitas sikap yaitu menunjukkan besar kecilnya kecenderungan bertindak atau berperilaku seseorang terhadap objek sikap. ${ }^{14}$

Adapun ciri-ciri sikap dalam upaya membedakan sikap dengan pendorongpendorong yang lain, ada beberapa ciri - ciri dari sikap, antara lain :

a) Sikap itu tidak di bawa sejak lahir. Hal ini berarti bahwa manusia pada waktu dilahirkan belum membawa sikap-sikap tertentu sesuatu objek. Karena sikap tidak di bawa sejak individu lahir, ini berarti sikap -sikap itu terbentuk dalam perkembangan individu yang bersangkutan;

b) Sikap itu selalu berhubungan dengan objek sikap. Hal itu berarti sikap selalu terbentuk atau dipelajari dalam hubungannya terhadap objek - objek tertentu yaitu melalui proses persepsi terhadap objek tertentu.

c) sikap dapat tertuju pada satu objek saja, tetapi juga dapat tertuju pada sekumpulan objek-objek. Hal ini berarti bila seseorang mempunyai sikap negatif pada seseorang, orang tersebut akan mempunyai kecenderungan untuk menunjukkan sikap yang negatif pula kepada kelompok di mana seseorang tersebut tergabung di dalamnya.

d) sikap itu dapat berlangsung lama atau sebentar. Hal ini berarti kalau sesuatu sikap telah terbentuk dan telah merupakan nilai dalam kehidupan seseorang, secara relatif sikap itu lama bertahan pada diri orang yang bersangkutan;

e) sikap itu mengandung faktor perasaan dan motivasi 15 .

Inti dari penegakan hukum menurut Soerjono Soekanto, adalah terletak pada kegiatan menyerasikan hubungan nilai-nilai yang terjabarkan di dalam kaidah-kaidah yang mantap dan mengejawantah dan sikap tindak sebagai rangkaian penjabaran nilai tahap akhir, untuk menciptakan, memelihara, dan mempertahankan kedamaian pergaulan hidup, bahkan dalam melaksanakan pembangunan secara menyeluruh di berbagai aspek. $^{16}$

Selanjutnya menurut Soerjono Soekanto, masalah pokok penegakan hukum sebenarnya terletak pada faktor-faktor yang mungkin mempengaruhinya. Faktor-faktor

\footnotetext{
14 Fence Wantu, Cs. Psikologi Anti Korupsi. Yogyakarta: Pustaka Belajar, 2012, hlm. 96

15 Ibid. hlm. 98-99.

16 Gatra, D., Pasamai, S., Kadir, H., Buana, A., \& Aswari, A. Stagnancy of Land Use Arrangement Former Cultivation Rights, Substantive Justice International Journal Of Law, Vol. 1, No. 1, 2018., hlm.1-8.
} 
tersebut mempunyai arti yang netral, sehingga dampak positif atau negatifnya terletak pada isi faktor-faktor tersebut. Faktor-faktor tersebut adalah sebagai berikut:

a. Faktor hukumnya sendiri;

b. Faktor penegak hukum, yakni pihak-pihak yang membentuk maupun menerapkan hukum;

c. Faktor sarana atau fasilitas yang mendukung penegakan hukum;

d. Faktor masyarakat, yakni lingkungan di mana hukum tersebut berlaku atau diterapkan;

e. Faktor kebudayaan, yakni sebagai hasil karya, cipta, dan rasa yang didasarkan pada karsa manusia di dalam pergaulan hidup;

Kelima faktor tersebut saling berkaitan dengan eratnya, oleh karena merupakan esensi dari penegakan hukum, juga merupakan tolak ukur daripada efektivitas penegakan hukum.

Menurut Purbacaraka dan Soekanto (dalam bukunya Soekanto), faktor hukumnya itu sendiri misalnya berupa undang-undang, supaya undang-undang tersebut dapat mencapai tujuannya, sehingga efektif, maka perlu mengandung beberapa asas. Asas-asas tersebut antara lain:

a. Undang-undang tidak berlaku surut

b. Undang-undang yang dibuat oleh penguasa yang lebih tinggi, mempunyai kedudukan yang lebih tinggi pula.

c. Undang-undang yang bersifat khusus menyampingkan undang-undang yang bersifat umum, apabila pembuatnya sama

d. Undang-undang yang berlaku belakangan, membatalkan undang-undang yang berlaku terdahulu.

e. Undang-undang tidak dapat diganggu gugat.

f. Undang-undang merupakan suatu sarana untuk mencapai kesejahteraan spiritual dan material bagi masyarakat maupun pribadi, melalui pelestarian ataupun pembaharuan (inovasi).

Soerjono Soekanto, terhadap penegakan hukum yang berasal dari undang-undang, mengemukakan beberapa gangguan yang mungkin terjadi, antara lain:

a. Tidak diikutinya asas-asas berlakunya undang-undang.

b. Belum adanya peraturan pelaksanaan yang sangat dibutuhkan untuk menerapkan undang-undang. 
c. Ketidakjelasan dalam arti kata-kata yang di dalam undang-undang yang mengakibatkan kesimpangsiuran di dalam penafsiran serta penerapannya.

Hukum menurut Soerjono Soekanto, Pembahasan mengenai penegak, sebenarnya lebih banyak tertuju pada diskresi. Diskresi menyangkut pengambilan keputusan yang tidak sangat terikat oleh hukum, dimana penilaian pribadi juga memegang peranan. Di dalam penegakan hukum diskresi sangat penting karena:

a. Tidak ada perundang-undangan yang sedemikian lengkapnya, sehingga dapat mengatur semua perilaku manusia

b. Adanya suatu kelambatan-kelambatan untuk menyesuaikan perundangundangan dengan perkembangan-perkembangan di dalam masyarakat, sehingga menimbulkan ketidakpastian.

c. Kurangnya biaya untuk menerapkan perundang-undangan sebagaimana yang dikehendaki oleh pembentuk undang-undang.

d. Adanya kasus-kasus individual yang memerlukan penanganan secara khusus.

Lawrence Meir Friedman menyebutkan berhasil atau tidaknya penegakan hukum bergantung pada tiga unsur yakni: struktur, substansi, dan budaya hukum, satu sama lain memiliki hubungan kuat.

a. Substansi Hukum adalah norma (aturan, keputusan) hasil dari produk hukum.

b. Struktur Hukum diciptakan oleh sistem hukum yang mungkin untuk memberikan pelayanan dan penegakan hukum.

c. Budaya hukum adalah ide, perilaku, keinginan, pendapat dan nilai-nilai yang berkaitan dengan hukum (positif/negatif)

\section{Analisis}

Analisis kaitannya dalam tiga unsur yang telah disebutkan menurut Lawrence Meir Friedman dalam penegakan hukum di Indonesia adalah sebagai berikut.

a) Substansi Hukum

Substansi hukum dapat dikatakan sebagai salah satu faktor yang memberikan kontribusi pada persoalan hukum. Cara sederhana, menjadikan norma hukum yang tidak jelas atau kabur (vagenorm). substansi hukum yang tidak jelas bukan hanya mudah untuk melakukan pelanggaran hukum, tetapi juga memberikan kesempatan yang luas untuk aparat penegak hukum untuk "frizzing" sesuai dengan masing-masing kepentingan. 
b) Struktur Hukum

Teori Lawrence Meir Friedman hal ini disebut sebagai sistem struktural yang menentukan bisa atau tidaknya hukum itu dilaksanakan dengan baik. Struktur hukum berdasarkan UU No. 8 Tahun 1981 tentang Hukum Acara pidana meliputi; mulai dari Kepolisian, Kejaksaan, Pengadilan dan Badan Pelaksana Pidana (Lapas). Kewenangan lembaga penegak hukum dijamin oleh undangundang. Sehingga dalam melaksanakan tugas dan tanggungjawabnya terlepas dari pengaruh kekuasaan pemerintah dan pengaruh-pengaruh lain. ${ }^{17}$

c) Budaya Hukum

Kultur atau budaya hukum menurut Lawrence Meir Friedman, adalah sikap manusia terhadap hukum dan sistem hukum-kepercayaan, nilai, pemikiran, serta harapannya. Kultur hukum adalah suasana pemikiran sosial dan kekuatan sosial yang menentukan bagaimana hukum digunakan, dihindari, atau disalahgunakan. Budaya hukum erat kaitannya dengan kesadaran hukum masyarakat. Semakin tinggi kesadaran hukum masyarakat maka akan tercipta budaya hukum yang baik dan dapat mengubah pola pikir masyarakat mengenai hukum selama ini. Secara sederhana, tingkat kepatuhan masyarakat terhadap hukum merupakan salah satu indikator berfungsinya hukum. Masyarakat Indonesia sendiri belum terlalu paham dan patuh dengan proses hukum yang ada. Pelaksanaan hukum di Indonesia pun belum tampak adil.

Adapun upaya-Upaya Menghindarkan Penggunaan Dana Desa Dari Perbuatan Korupsi adalah sebagai berikut:

1. MoU dengan masyarakat

MoU dengan masyarakat merupakan hal yang sangat penting untuk dilakukan dikarenakan bisa menciptakan tatanan yang harmonis karena memiliki komitmen yang tinggi dalam memaksimalkan program dana desa sehingga hal tersebut jelas akan terlaksana sesuai dengan prosedur yang ada.

2. Tim pengawasan dana desa

Adanya tim pengawas yang bersifat independen dengan membuka seluruh ruang gerak masyarakat tanpa meminta keterwakilan terhadap pengawasan dana desa dengan tidak membatasi siapa saja untuk mari bersama-sama

17 M. D. Matutu, A. Latief \& H. Mustamin, Mandat, Delegasi, Attribusi dan Implementasinya di Indonesia. YogyakartaL UII Press. 2004. 
mengawasi penggunaan dana desa serta selalu bersosialisasi terhadap semua program pembangunan yang ada didesa dengan tujuan berkomitmen membangun desa secara bersama.

3. Siap di Sumpah

Sumpah selama ini dianggap hal yang biasa dikarenakan sumpah itu hanya bisa di gunakan ada saat-saat tertentu saja seperti halnya pada saat bersumpah di pengadilan atau kapan pun, akan tetapi keberadaan sumpah di yakini sangat ampuh untuk bisa menciptakan rasa keterbukaan karena khawatir akan mengalami sanksi dari tuhan yang maha esa, sehingga upaya menghindarkan penggunaan dana Desa dari perbuatan korupsi harus siap di sumpah dengan menggunakan kitab suci masing-masing agama.

4. Sanksi yang tegas

Penegakan hukum berupa sanksi pun bisa berimplikasi pada efek jera dikarenakan akan berdampak pada persoalan harga diri ataupun moral yang tidak baik yang akan dilihat oleh masyarakat serta akan menjadi perbincangan yang merusak harga diri pribadi maupun keluarga.

\section{KESIMPULAN}

Berdasarkan hal tersebut di atas penulis menyimpulkan bahwa agar kiranya upaya penyelamatan dana desa pada penggunaan dana desa dari perbuatan korupsi adalah sebagai berikut: Pertama, MoU dengan masyarakat dengan tujuan berkomitmen membangun desa secara bersama tim pengawasan dana desa; Kedua, pembentukan tim pengawas yang independen untuk mengawasi jalannya proses pengelolaan dana desa; ketiga, siap disumpah yaitu aparat desa di sumpah dengan menggunakan kitab suci masing-masing agama; keempat sanksi yang tegas dengan tujuan untuk memberikan kepada pelaku penyalahgunaan dana desa. Sehingga diharapkan bahwa Aparat Desa, dapat berkomitmen dengan sungguh dalam pengelolaan dana desa, sehingga tidak berniat untuk melakukan korupsi begitu pula dengan masyarakat Desa, dapat melibatkan diri secara aktif, yang dimulai dari proses perencanaan, pelaksanaan dan evaluasi terhadap penggunaan dana desa, sehingga proses pembangunan desa dapat terealisasi. 


\section{Daftar Pustaka}

\section{Buku}

Irianto, Sulistyowati dan Shidarta (ed), Metode Penelitian Hukum; Konstelasi dan Refleksi, Jakarta: Yayasan Pustakan Obor Indonesia, 2011.

Matutu, M. D., Latief, A., \& Mustamin, H. Mandat, Delegasi, Atribusi dan Implementasinya di Indonesia. Yogyakarta: UII Press. 2004

Soekanto, Soerjono, Pengantar Penelitian Hukum Jakarta: UI Press, 2007.

W. Bimo, Psikologi Sosial Suatu pengantar, Edisi Revisi, Yogyakarta: Andi Opset, 2013.

Wantu, Fence, Psikologi Anti Korupsi. Yogyakarta: Pustaka Belajar. 2012.

M.J. Yoltuwu. Pertumbuhan Ekonomi di Daerah Tertinggal (Economic Growth in Disadvantage Area). In Work Meeting Presentation, Ministry of Disadvantage Area Development, Republic of Indonesia, 2013.

\section{Jurnal}

Aswari, Aan Sibernetika, Teknologi Siber dan Kebutuhan Hukum. Jurnal Lentora, Vol. 3, No. 2, 2016.

Djanggih, Hardianto, The Phenomenon Of Cyber Crimes Which Impact Children As Victims In Indonesia. Yuridika, Vol. 33, No. 2, 2018.

Gatra, D., Pasamai, S., Kadir, H., Buana, A., \& Aswari, A. Stagnancy of Land Use Arrangement Former Cultivation Rights. Substantive Justice International Journal Of Law, Vol. 1, No. $1,2018$.

Makhmudah, Maratul, Pencegahan Terhadap Tindak Pidana Korupsi Pemerintahan Desa: Kajian Politik Kebijakan Dan Hukum Pengelolaan Sumber Daya Alam Desa, Fakultas Hukum Universitas Islam Malang, Fakultas Hukum Universitas Brawijaya Malang”. Yustisia 95 Mei-Agustus 2016.

Permatasari, Elfira, Habib Adjie, \& Hardianto Djanggih, Perlindungan Hukum Kepemilikan Tanah Absentee yang Diperoleh Akibat Pewarisan. Varia Justicia, Vol. 14, No. 1, 2018,

\section{Internet}

Obral, Madril, O., Remisi untuk Koruptor. http://digilib.um.ac.id. Diakses pada tanggal 7 Mei 2018.

Wedhaswary, Inggried Dwi, Nawa Cita", 9 Agenda Prioritas Jokowi-JK, https://nasional.kompas.com/read/2014/05/21/0754454/.Nawa.Cita.9.Agenda.Pr ioritas.Jokowi-JK. Diakses pada tanggal 1 Maret 2018. 